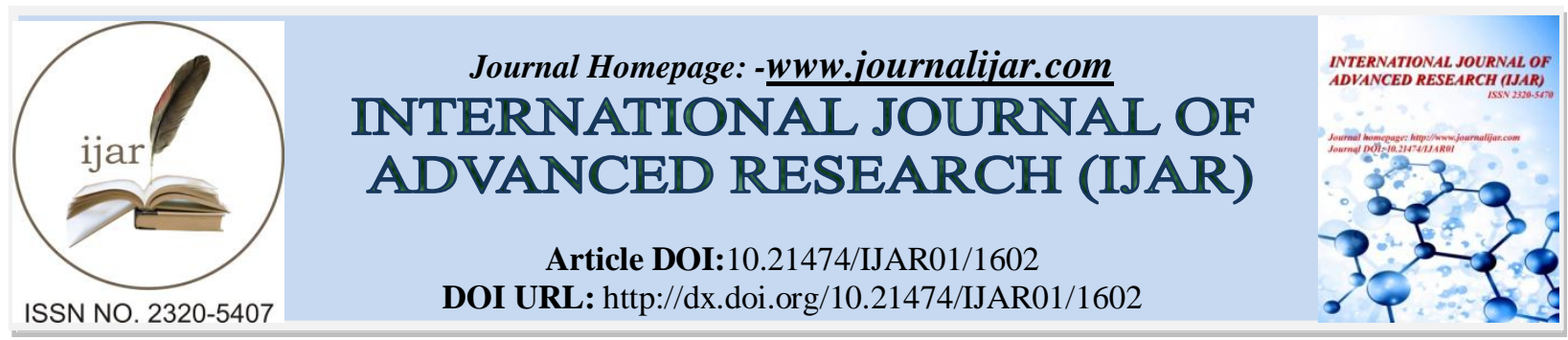

RESEARCH ARTICLE

\title{
EVALUATING THE IMPACT OF AVAILABILITY OF SOLAR ENERGY PRODUCTS ON ITS USE AMONG THE PEOPLE OF MUMBAI, INDIA.
}

\section{Dr. Anupamaa S. Chavan ${ }^{1}$ and Dr. Madhav N. Welling ${ }^{2}$.}

1. Lecturer, SVKM's NarseeMonjee College of Comm. \& Eco Vile-Parle (W), Mumbai - 400 056; India.

2. Former Pro Vice-Chancellor, SVKM's NMiMS (Declared as Deemed to be University by UGC) Vile-Parle (W), Mumbai - 400 056; India.

\section{Manuscript Info}

\section{Manuscript History}

Received: 12 July 2016

Final Accepted: 19 August 2016

Published: September

201 Xxxxxxxxxxxxxxx

Key words:-

Energy resources, Renewable Energy

Resources, Solar energy, Sustainable

development, Solar Photovoltaic Energy,

Solar Thermal Energy.

\section{Abstract}

Energy is an important resource and is one of the driving forces behind economic progress. Energy becomes an inevitable component for economic development as also for improving and maintaining the quality of life. Solar energy is a very large renewable, clean and green source of energy. Solar energy could fulfill all the present and future energy needs of the world on a continuous basis to achieve Sustainable Development. This research paper attempts to investigate and study the significance of availability of Solar Energy Products on its use among the people of Mumbai, India.

Copy Right, IJAR, 2016,. All rights reserved.

\section{Introduction:-}

Energy is an important resource and one of the driving forces behind economic progress. Energy becomes an inevitable component for economic development as also for improving and maintaining the quality of life. Recent developments in energy markets show that energy security concerns are becoming more acute. These include a tightened global energy supply/demand balance, soaring energy prices, growing geo-political risks, and the emerging tendency of nationalism. The world is facing a twin energy related threats, that of not having adequate and secured supplies of energy at affordable prices and of environmental harm caused by consuming too much of it. Soaring energy prices and recent geo-political events have reminded us of the essential role affordable energy plays in economic growth and human development as well as of the vulnerability of the global energy system to supply disruptions.

Yet the current pattern of energy supply carries the threat of severe and irreversible environmental damage including changes in global climate. Reconciling the goals of energy security and environmental protection requires strong and co-ordinated government action and a favourable consumer attitude. G-8 leaders meeting with the leaders of several major developing countries and heads of international organizations including the International Energy Agency (IEA) at Gleneagles in July 2005 and at St. Petersburg in July 2006 called on the IEA to "advice on alternative energy scenarios and strategies aimed at a clean, clever, and competitive energy future." This paper studies all the energy options, their pros and cons as also suggests why solar energy should be used. It also tries to investigate and study the significance of availability of Solar Energy Products on their use among the people of Mumbai. India.

Corresponding Author:-Mrs. Anupamaa S. Chavan.

Address:-Lecturer, SVKM's Narsee Monjee College of Comm. \& Eco Vile-Parle (W), Mumbai - 400 056; India. 


\section{Objectives:-}

This paper includes the following objectives:

1. To be acquainted with the different types of Energy Resources.

2. To comprehend Solar Energy and its types.

3. To find out the response of buyers/prospective buyers towards the Awareness and Availability of Solar Energy Products.

4. To determine whether Availability of Solar Energy Products has significant impact on their use.

\section{Different types of Energy Resources:-}

There are basically two sources of energy: Renewable and Non-Renewable. Renewable energy sources can be replenished in a short period of time they are; Biomass, Hydropower, Geothermal power, Wind power, and Solar energy.Non-Renewable energy resources are those which cannot be readily replaced by natural means on a level equal to its consumption, e.g. Oil (petroleum), Natural gas, Coal and Nuclear energy. Every nation in the world has to think of alternative energy resources. As the development of any nation also depends on the availability of energy resource, it has to make sure that it is available and is sustainable in nature. India's present economic growth as stated by National Productivity Council (2009) is about $8 \%$ to $9 \%$ per year, which is causing a lot of stress on commercial energy resources, most of which are from fossil fuels. It is a well known fact that increased use of fossil fuels is causing detrimental effect on the environment due to more green house gas emissions in the form of carbon dioxide, sulphur dioxide and nitrogen oxide. India's proven coal reserves are estimated to be 70 billion MT consisting of mainly low grade coal. It may last for not more than 200 years. Known oil and natural gas reserves may last only for about 18 and 25 years respectively. India imports nearly $70 \%$ of oil requirement, with rising prices of crude oil, it is eating up a large portion of export earnings.

If we compare the options available in renewable energy resources we have followingoptions:

- Biomass has environmental implications and its use is being examined after taking into consideration the biodiversity and pollution effect aspects. Though Biomass is a renewable fuel its use can still contribute to global warming.

- Hydropower plants installed to generate electricity also create problems like human displacements and are damaging the ecosystem. Environment concerns about the effects of reservoirs may prohibit development of hydropower.

- Geothermal energy is derived from fluids drawn from deep inside earth which carry a mixture of gases with them, notably carbon dioxide and hydrogen sulphide. When released in the environment, these pollutants contribute to global warming, acid rain, and noxious smells in the vicinity of the plant. In addition to dissolved gases, hot water from geothermal sources may contain trace amount of dangerous elements such as mercury, arsenic, and antimony which, if disposed of into rivers, can render the water unsafe to drink. Construction of the power plants can adversely affect land stability in the surrounding region. Enhanced geothermal systems can trigger earthquakes as part of the hydraulic fracturing process. In 2009 the project in Basel, Switzerland was suspended because more than 10,000 seismic events measuring up to 3.4 on the Richter scale occurred over the first 6 days of water injection.

- Wind energy requires a large area of land to install wind turbines; again the intensity of the wind also fluctuates. Studies in UK have shown that if on shore turbines are placed in a straight line then an increased risk of aerodynamic modulation can occur which can result in noise nuisance to the nearby residents.

- Solar energy becomes a very good choice, reason being that it is freely available everywhere and it is a clean as well as quiet source of energy without any greenhouse gas emissions thus avoiding global warming. At night when there is no Sun we are required to use the energy generated and stored during the day. The use of solar energy products are not much though they have good utility, high cost of installation makes these product expensive.

\section{What is Solar Energy?}

Energy of the Sun has been used ever since humans existed on this planet. As far back as 5,000 years ago people worshipped THE SUN, 'Ra', the Sun God who was considered the first king of Egypt. In Mesopotamia, the Sun God, Shamash, was a major deity and was equated with justice. In Greece there were two Sun deities, Apollo and Helios. The influence of the Sun also appears in other religions -- Zoroastrianism, Mithraism, Roman religion, Hinduism, Buddhism, the Druids of England, the Aztecs of Mexico, the Incas of Peru, and many Native American tribes. Sun is an important star of our planet. Without it, life would not exist on this earth; we use the Sun's energy every day in many different ways, when we hang laundry outside to dry in the Sun, we are using the Sun's heat to do 
the work - drying our clothes. Plants use the sunlight to make food for them. Animals eat plants for food. Thus Sun becomes an important component for living beings. Fossil fuels such as coal, oil, and natural gas are also formed due to decaying of plants hundreds of millions of years ago due to sunlight. Indirectly the Sun or other stars are responsible for all our energy. Even Nuclear energy derived is from a star because the uranium atoms used in nuclear energy were created from the deposits of an exploded star- Nova. Thus Solar energy i.e. energy derived from Sun, becomes an important source of energy in today's world when the conventional sources of energy i.e. coal, oil, natural gas, are depleting and one needs to seriously think about the non-conventional sources of energy which are renewable and also help in sustainable development. Sustainable development was defined by the United Nations World Commission on Environment and Development in the 1987's Brundtland Report as "those paths of social, economic and political progress that meet the needs of the present without compromising the ability of future generations to meet their own needs."

Thus Solar energy being a non-conventional source of energy can be one of the renewable energy sources which is received free of cost from the Sun; becomes important and inevitable.

Solar energy can be used in the following two ways:

\section{Solar Photovoltaic Energy (Light energy):-}

It is the direct conversion of sunlight into electricity. Sunlight is converted into electricity using photovoltaic or solar cells. Photovoltaic (PV) cells are semi-conductor devices, usually made of silicon, which contain no liquid, corrosive chemicals or moving parts. They produce electricity as long as they are exposed to light. They require little maintenance, do not pollute environment and they operate silently, thus making photovoltaic energy the cleanest and safest method of power generation. Through the solar photovoltaic route, solar home lights, solar street lights, solar generators, solar lanterns, solar traffic lights, solar road studs, solar blinkers and so on are the most common devices and systems that are being widely used.

\section{Solar Thermal Energy (Heat energy):-}

It is a technology for harnessing solar energy for thermal (heat) energy. Solar thermal collectors are flat plates generally available as low, medium or high temperature collectors. Low and medium temperature collectors are generally used for water heating for residential and commercial purposes. High temperature collector concentrates sunlight using mirrors or lenses and is generally used for production of electric power. Solar thermal energy can also be used for water heating, air heating, cooking, drying of agricultural and food products, distillation of water, water purification, detoxification of waste, cooling and refrigeration, process heat for industry and electricity generation.

\section{Review of Literature:-}

Vipradas (2001) in Renewables - Products and Markets a compilation of papers edited by him states that wide acceptance in the society regarding the inter-linkages among environment, poverty, and sustainable development forces our attention to technological solutions that address the needs of today without producing any negative externalities. It is in this regard that RET's (Renewable Energy Technologies) have gained immense popularity. The editor further emphasizes that technology and installations have to be provided with due regard to replication and integration into long-term development strategies. This, in turn, necessitates the spread of these technologies through market channels requiring the provision of a maintenance and after-sales servicing infrastructure. A paper presented by Amit Kumar (2001) on Solar pond technology states that solar pond technology is one such renewable energy option that offers various cost-effective end-uses without endangering the environment. Salinity gradient solar ponds in suitable locations are essentially low-cost solar collectors with integrated storage and, hence are potentially cheaper alternatives to flat plate collector system.

International Energy Agency (IEA), (2006) World Energy Outlook published by, IEA which is an autonomous body established in November 1974 within the framework of the Organization of Economic Co-operation and Development (OECD) to implement an international energy programme. IEA aims at improving the world's energy supply and demand structure by increasing the efficiency of energy use. It basically stresses more on how to improve system for coping with oil supply disruptions. The book states that the world is facing twin energy- related threats; that of not having adequate and secure supplies of energy at affordable prices and that of environmental harm caused by greenhouse gas emissions by consuming too much of it. The current pattern of energy supply carries the threat of severe and irreversible environmental damage- including change in global climate. It also states that reconciling the goals of energy security and environmental protection requires strong and co-ordinated Government 
action as well as public support. Thus IEA stresses more on the use of non - conventional use of energy resource thus solar energy being one of them becomes inevitable.

The Energy Resource Institute i.e. TERI, (2007) Energy Data Directory year book states that Photovoltaic (PV) technology was initially developed during the late 1950 's to provide long term reliable power for satellites. Companies began to offer PV technology for commercial application in the mid- 1970s. India has a PV manufacturing history of more than two decades. Production of Solar photovoltaic (SPV) cells has grown at an average rate of 28\% per annum during 1996-2005, while solar module manufacturing has grown at an average rate of $30 \%$ during the same period. The SPV systems are being promoted in India primarily for rural and remote applications. A 2.9-MW system based on SPV is feeding power to the grid. The decentralized systems are solar power plants, with mini grids, solar home lighting systems, solar lanterns, and solar street lights. However in terms of contribution, the percentage of total amount of electricity generated in India is very small owing to very small installed capacity - about 87MW compared to total power generation capacity of 12,736 MW. The target for Eleventh Five - year Plan period, that is till 2012, is to add about 50 MW of SPV systems (includes both off-grid and grid-connected SPV systems). Financial assistance is provided as per the provisions under various schemes by Ministry for Non Renewable Energy. (MNRE)

Pandey, (2007) in the book titled, Environmental Management states in the chapter on Renewable Energy Resources, that energy potential of a nation has direct correlation with economic growth and prosperity. The stage of development is well reflected by the per capita energy consumption of a country. The deepening energy crisis, with which the world community is confronted with, has led to the formulation of an energy policy framework within which the rate of growth and pattern of energy consumption could be regulated. In this context, a transition may be considered necessary. The required transition is to shift from fossil and non - renewable sources such petroleum, coal, and uranium to renewable energy sources. Thus solar energy will play an important role in managing various energy related problems.

Uberoi, (2007) in his book on Environmental Management states that, Energy is an essential need for human existence. There is shortage of energy due to fast depletion of fossil fuels and the increase in demand for energy due to the increase in population and the growth of industry. The energy demands are increasing while conventional energy sources are diminishing at a much faster rate. The rising energy demand has resulted in the setting up of more power plants which are based primarily on fossil fuel (coal, oil, gas). The fossil fuels based plants not only emit green house gases like Carbon dioxide $\left(\mathrm{CO}_{2}\right)$ but also generate fly-ash which is dangerous to human health. The emission of $\mathrm{CO}_{2}$ the maingreen gas, is expected to surpass that of the OCED countries by the year 2015. Hydro plants have also been installed to generate energy but these plants also create problems like human displacement and are damaging the ecosystem. The nuclear option comes with its own set of problems. Uncertainties surrounding the safety and economics of radioactive waste disposal and decommissioning remain. The recent mishap at Tokaimura, Japan shows that the danger of a nuclear accident is still very real. The use of biomass again should be equated with rate of consumption. The use of solar energy can be another very good option for renewable energy resource. It is freely available and a very clean and quite source of energy generation. The author further states that the Government at the centre and at the State level, and their agencies should become proactive vis-à-vis environment. The environmental problems cannot be tackled without a sound proactive policy by the Government. Intervention of the Government is required on continuing basis and not on one-time legislation and its implementation. Corporate behavior can be regulated or altered through state policies. The policies of Government can shape the role of companies and that of the managers for the larger interest of society. The corporate world in India, under new economic order of liberalization and globalization has to increase its share of world trade and in this effort one major impact of rising trades would be on environment and resources. The business world internationally has begun to acknowledge that environment is playing an important role in all facets of business. A survey by Mckinsey and company (2009) revealed that: (1) $92 \%$ of CEO's believe that environment should be top management priority; (2) $35 \%$ CEO's believe that their companies have adopted strategies to anticipate impacts of environment on business. Thus environment management is gaining a lot of momentum in today's corporate world.

Very less has been found and done in the area of solar energy products. Thus there is not much literature available for the review. 
Government of India provides Credit/loan facility at 5\% interest for buying solar energy products. As per IREDA (2013), [Online], "Indian Renewable Energy Development Agency Limited (IREDA) was incorporated on 11th March, 1987 as a Public Limited Government Company under the Indian Companies Act, 1956 and it promotes, develops and extends financial assistance for Renewable Energy and Energy Efficiency/Conservation Projects.

- IREDA has been notified as a 'Public Financial Institution' under section 4 'A' of the Companies Act, 1956 and registered as Non-Banking Financial Company (NFBC) with Reserve Bank of India (RBI).

- IREDA's mission is to be a pioneering, participant friendly and competitive institution for financing and promoting self-sustaining investment in energy generation from Renewable Sources, Energy Efficiency and Environmental Technologies for sustainable development.

One of the main objectives of IREDA is to give financial support to specific projects and schemes for generating electricity and / or energy through new and renewable sources and conserving energy through energy efficiency.

\section{Research Methodology:-}

This research paper studies, the impact of availability of Solar Energy Products on its use among people of Mumbai, India. The study was conducted in the city of Mumbai and its suburbs. Data was collected through personal interviews, telephonic calls, and emails. Questionnaire was distributed amongst eighty six respondents out of which seventy were considered complete. The respondents were questioned regarding the availability ofSolar Energy Products. They were also asked to rate their response on a five point Likert scale ranging from Strongly Disagree (1) to Strongly Agree (5). Respondents consisted of Private Residential Owners, Co-operative Societies New constructions, Hospitals, Industries, Hotels, Education Institutions, Public Utilities, Places of Worship, and Recreation Centres.

\section{Scope and Limitations of the Study:-}

- This study is restricted to the city of Mumbai and its suburbs situated in the state of Maharashtra, India.

- The study focuses only on four solar energy products- Solar Water Heaters, Solar Street Lights,Solar LED Lights and Solar Inverters, other solar energy products are excluded.

- Only one factor i.e. Product Availability, which influences the use of Solar Energy Products was taken into account for this study, other factors which might influence the use of Solar Energy Products such as Cost, Credit Facility, After Sale Service and Government Incentives/Subsidies etc are not considered.

\section{Hypothesis of the Study:-}

- $\mathrm{H}_{\mathrm{o}}$ : Easy availability of Solar Energy Products has no significant impact on the use of Solar Energy Products.

- $\mathrm{H}_{1}$ : Easy availability of Solar Energy Products has significant impact on the use of Solar Energy Products.

Findings:-

Table 1 shows the number of users and non-users in the sample of Solar Energy Products.

Table 1:-Number of Users and Non Users of Solar Energy Products

\begin{tabular}{|c|c|c|c|}
\hline Users & Response & Frequency & Percentage \\
\hline \multirow{2}{*}{ Solar Water Heater } & YES & 11 & 15.71 \\
\cline { 2 - 4 } & NO & 59 & 84.29 \\
\hline \multirow{2}{*}{ Solar Street Lights } & YES & 6 & 8.57 \\
\cline { 2 - 4 } & NO & 64 & 91.43 \\
\hline \multirow{2}{*}{ Solar LED Lights } & YES & 6 & 8.57 \\
\cline { 2 - 4 } & NO & 64 & 91.43 \\
\hline \multirow{2}{*}{ Solar Inverters } & YES & 3 & 4.29 \\
\cline { 2 - 4 } & NO & 67 & 95.71 \\
\hline
\end{tabular}

It can be noted from Table 1 that among seventy respondents only eleven (15.71\%) were using solar water heaters, six $(8.57 \%)$ were using solar street lights and solar LED lights and only three (4.29\%) respondents were using solar inverters. 
Table 2 given below shows responses regarding the awareness and the availability of solar energy products.

Table 2:- Awareness \& Availability of Solar Energy Products

\begin{tabular}{|c|c|c|c|c|c|}
\hline \multirow[t]{2}{*}{ PRODUCTS } & & \multicolumn{2}{|c|}{ AWARENESS } & \multicolumn{2}{|c|}{ AVAILABILITY } \\
\hline & & FREQ & $\%$ & FREQ & $\%$ \\
\hline \multirow[t]{3}{*}{ SOLAR WATER HEATERS } & YES & 70.00 & 100 & 40.00 & 57.14 \\
\hline & NO & 00.00 & 00 & $\mathbf{1 7 . 0 0}$ & 24.29 \\
\hline & DON'T KNOW & 00.00 & 00 & 13.00 & 18.57 \\
\hline \multirow[t]{3}{*}{ SOLAR STREET LIGHTS } & YES & 69.00 & 98.57 & 26.00 & 37.14 \\
\hline & NO & 0.00 & 00.00 & 21.00 & $\mathbf{3 0 . 0 0}$ \\
\hline & DON'T KNOW & 1.00 & 1.43 & 23.00 & 32.86 \\
\hline \multirow[t]{3}{*}{ SOLAR LED LIGHTS } & YES & 44.00 & 62.86 & 18.00 & 25.71 \\
\hline & NO & 12.00 & $\mathbf{1 7 . 1 4}$ & 20.00 & 28.57 \\
\hline & DON'T KNOW & 14.00 & 20.00 & 32.00 & 45.71 \\
\hline \multirow[t]{3}{*}{ SOLAR INVERTERS } & YES & 49.00 & 70.00 & 17.00 & 24.29 \\
\hline & NO & 13.00 & 18.57 & 20.00 & 28.57 \\
\hline & DON'T KNOW & 8.00 & 11.43 & 33.00 & 47.14 \\
\hline
\end{tabular}

From Table 2One can see that:

- $70(100 \%)$ respondents were aware about Solar Water Heaters (SWHs), it means that all the respondents knew that SWHs exist. $40(57.14 \%)$ of the respondents opined that SWHs are easily available and $17(24.29 \%)$ respondents opined that SWHs are not easily available, whereas 13 (18.57\%) respondents did not know whether they are easily available.

- $69(98.57 \%)$ of the respondents were aware about Solar Street Lights (SSLs), it means that almost all the respondents knew that SSLs exist except one respondent who did not know anything about it.26 (3.14\%) of the respondents opined that SSLs are easily available and 21(30\%) respondents opined that SSLs are not easily available, whereas $23(32.86 \%)$ respondents did not know whether they are easily available.

- $44(62.86 \%)$ of the respondents were aware about Solar LED Lights (SLLs), 12(17.14\%) said no and 14(20\%) did not know about SLLs. 18 (25.71\%) of the respondents opined that SLLs are easily available and 20(28.57\%) respondents opined that SLLs are not easily available, whereas 32 (45.71\%) respondents did not know whether they are easily available.

- $49(70 \%)$ of the respondents were aware about Solar Inverters (SIs), 13(18.57\%) said no and 8(11.43\%) did not know about SIs. $17(24.29 \%)$ of the respondents opined that SIs are easily available and $20(28.57 \%)$ respondents opined that SIs are not easily available, whereas $33(47.4 \%)$ respondents did not know whether they are easily available.

The analyses of the responses collected from users and non- ignorant non-users were done under Mann Whitney Wilcoxon Test and accordingly interpretations/conclusions were made.

Table 3:- Mann Whitney WilcoxenTest result

\begin{tabular}{|c|c|c|c|c|c|c|}
\hline Particulars & Users & $\begin{array}{c}\text { Non- } \\
\text { Ignorant } \\
\text { Non Users } \\
\end{array}$ & $\begin{array}{c}\text { p-value } \\
(z)\end{array}$ & Z-Statistic & Decision & Conclusion \\
\hline $\begin{array}{l}\text { SOLAR WATER } \\
\text { HEATERS ARE } \\
\text { EASILY } \\
\text { AVAILABLE }\end{array}$ & 11 & 57 & 0.0051 & -2.8029 & $\begin{array}{c}\text { REJECT } \\
\mathbf{H}_{0}\end{array}$ & $\begin{array}{c}\text { There is } \\
\text { Significant } \\
\text { Difference } \\
\text { between USER } \\
\text { and NOT- } \\
\text { IGNORANT } \\
\text { NON USERS }\end{array}$ \\
\hline $\begin{array}{l}\text { SOLAR STREET } \\
\text { LIGHTS ARE } \\
\text { EASILY } \\
\text { AVAILABLE }\end{array}$ & 6 & 58 & 0.0012 & -3.2283 & $\begin{array}{c}\text { REJECT } \\
\mathbf{H}_{0}\end{array}$ & $\begin{array}{c}\text { There is } \\
\text { Significant } \\
\text { Difference } \\
\text { between USER } \\
\text { and NOT- } \\
\text { IGNORANT } \\
\text { NON USERS }\end{array}$ \\
\hline
\end{tabular}




\begin{tabular}{|c|c|c|c|c|c|c|}
\hline $\begin{array}{l}\text { SOLAR LED } \\
\text { LIGHTSARE } \\
\text { EASILY } \\
\text { AVAILABLE }\end{array}$ & 6 & 42 & 0.1192 & -1.5582 & $\begin{array}{c}\text { ACCEPT } \\
\text { H }_{0}\end{array}$ & $\begin{array}{c}\text { There is NO } \\
\text { Significant } \\
\text { Difference } \\
\text { between USER } \\
\text { and NOT- } \\
\text { IGNORANT } \\
\text { NON USERS }\end{array}$ \\
\hline $\begin{array}{l}\text { SOLAR } \\
\text { INVERTERS } \\
\text { ARE EASILY } \\
\text { AVAILABLE }\end{array}$ & 2 & 51 & 0.0264 & -2.2206 & $\begin{array}{c}\text { REJECT } \\
\mathbf{H}_{0}\end{array}$ & $\begin{array}{c}\text { There is } \\
\text { Significant } \\
\text { Difference } \\
\text { between USER } \\
\text { and NOT- } \\
\text { IGNORANT } \\
\text { NON USERS }\end{array}$ \\
\hline
\end{tabular}

From the Table 3, it can be seen that, out of seventy respondents, responses of users and non-ignorant non-users were considered; ignorant non-users were not considered as they were not able to give their response at all.

Following conclusionsarederived using Mann Whitney Wilcoxon Test:

\section{Solar Water Heaters:-}

We reject:

$\mathrm{H}_{\mathrm{o}}$ : Easy availability of Solar Energy Products has no significant impact on its use.

Stronger the agreement with 'AVAILABILITY OF SOLAR WATER HEATERS' higher is the probability of using it. $(\mathrm{p}$-value $=0.0051)$.

\section{Solar Street Lights:}

We reject:

$\mathrm{H}_{\mathrm{o}}$ : Easy availability of Solar Energy Products has no significant impact on its use.

Stronger the agreement with 'AVAILABILITY OF SOLAR STREET LIGHTS' higher is the probability of using it. $(\mathrm{p}$-value $=0.0012)$.

\section{Solar LED Lights:}

We accept:

$\mathrm{H}_{\mathrm{o}}$ : Easy availability of Solar Energy Products has no significant impact on its use.

There is no significant impact of 'AVAILABILITY OF SOLAR LED LIGHTS' on the use of Solar LED Lights. (pvalue $=0.1192$ ).

\section{Solar Inveters:}

We reject:

$\mathrm{H}_{\mathrm{o}}$ : Easy availability of Solar Energy Products has no significant impact on its use.

Stronger the agreement with 'AVAILABILITY OF SOLAR INVERTERS' higher is the probability of using it. (pvalue $=0.0264$ ).

\section{Conclusion:-}

From the analyses of data one can interpret that availability of Solar Water Heaters, Solar Street Lights and Solar Inverters have significant impact on its use. Only for Solar LED Lights the availability factor is insignificant. Awareness regarding availability of solar energy productscan be created through extensive publicity with the help of various media mix.Manufacturers should heavily advertise about the availability of Solar Energy Products. Social advertisements in this regard can also be done by the Government which can help to create awareness about their availability.

\section{References:-}

\section{Books:-}

1. International Energy Agency. (2006). World Energy Outlook. Paris: OECD.

2. International Energy Agency. (2006). Energy Policies of IEA Countries. Paris: OECD. 
3. Kotler, Philip. (2006). Marketing Management. UK: Pearson Publication.

4. Noble, Duncan. And Swartman, K. Robert. (1995). The Canadian Renewable EnergyGuide. Burnstown: General Store Publishing House.

5. 5.Pandey, N.G. (2007). Environmental Management. New Delhi: Vikas Publishing House Pvt Ltd.

6. Panneerselvam, R. (2006). Research Methodology. New Delhi: Prentice Hall India Publishing.

7. Polonsky, Jay. Michael, and T, Alma. (Eds). (2008). Ecological Imperatives and the Role of Marketing by Sheth, N. Jagdish., Parvatiyar, Atul. Environmental Marketing. New York: Haworth Press.

8. Sukhatme, P. S. (2006). Solar Energy. New Delhi: Tata McGraw - Hill Publishing Co. Ltd.

9. S, Vandana. (2002). Alternative Energy. New Delhi: APH Publishing Corporation.

10. Terri Energy Data Directory. (2008). New Delhi: Terri Press.7

11. Uberio, K. N. (2007) Environmental management. New Delhi: Excel Books.

12. Vipradas, Mahesh. (Ed). (2001). Renewable Products and Markets. pp-95-120. New Delhi: Terri.

\section{Journals:-}

1. Rana, Z. (2010, February). Challenge to Business - Changes in India's Marketing Environment. Indian Journal of Marketing, Vol.40 (2). New Delhi.

2. 14.Shah, Praneti. (2010, February). Awareness \& Preference towards Carbon Credits - An Initiative to go for Green.Prabandhan: Indian Journal of Management, Vol. 3(2). New Delhi.

\section{Research Papers:-}

1. Roland-Holst, David. (2008, October). Energy Efficiency, Innovation, and Job Creationin California. Centre for Energy, Resources and Economic Sustainability: University of California.

2. Staudt, L. (2005, May 16). Energy Research, Development and Demonstrations. Paper submitted to Centre for Renewable Energy: Dundalk-IT.

\section{Newspapers:-}

1. Managing The Climate Change. (2009, Feb 27,Friday). The Times of India: Mumbai

2. Mitra, Soubhik. (2009, June 4, Thursday). Green Tech to Reduce Pollution. Hindustan Times: Mumbai.

3. Seeing Red.(2009, Jan. 13, Tuesday). Indian Express: Mumbai.

\section{Magazines:-}

1. Role of Education in Energy Conservation. (2009, Jan/Feb). Productivity News Vol.47. Mumbai: National Productivity Council.

2. Roy, Kisholoy. (2009, Feb).Green Retailing. Advertising Express. Vol. IX. Hyderabad: The ICFAI University Press.

3. The Solar. (2008, July).Vol.1.Issue 1. New Delhi: The Energy Research Institute.

\section{Websites:-}

1. 23. Easy to Understand Solar Energy Fundamentals. (2009, June 3). [On-Line] Available http://ezinearticles.com

2. 24. Energy Resource. (2008, Feb). [On-Line] Available http://www.energyquest.cogov/story/chapter15.html

3. 25. Main Renewable Energy Technology. (2009, June 1). [On-Line] Available. Wikipedia.org/wiki/energy resources

4. 26. Nayudu, Arti. (2008, Feb 26). Solar Energy and Marketing. [On-Line] Available. http://wwwclipclip.org

5. 27. Solar, Products and Equipment. (2009, March 18). [On-Line] Available. http://www.Solarsv.com

6. 28. Solar-energy-advantages-disadvantages. (2005, July 10). [On-Line] Available. http://www.ezinearticles.com

7. 29. Wikipedia. (2009, June 03). Environmental Impact. [On-Line] Available. http://en.wikipedia.org/wiki/geothermal_power.

8. 30. Wikipedia. (2009, May 31). Wind Power. [On-Line] Available. http://en.wikipedia.org/wiki/windpower.

9. 31. Government of India, Ministry of New and Renewable Energy (2015, September). Introduction. [On-line] Available. http://www.mnre.gov.in/mission-and-vision-2/

10. 32. Government of India, Indian Renewable Energy Development Agency Limited. (2015). Background. [Online] Available. http://www.ireda.gov.in/forms/contentpage.aspx?lid=820 